\title{
Demonstration of a non-steroidal, non-inhibin factor in the ovine corpus luteum of pregnancy that reduces pituitary responsiveness to $\mathrm{GnRH}$-induced $\mathrm{LH}$ secretion in vitro
}

\author{
P. A. Fowler ${ }^{1}$, N. P. Groome ${ }^{2}$ and K. H. Al-Gubory ${ }^{3}$ \\ ${ }^{1}$ Department of Obstetrics and Gynaecology, University of Aberdeen, Aberdeen AB25 2ZD, UK; \\ ${ }^{2}$ School of Biological and Molecular Sciences, Oxford Brookes University, Oxford OX3 OBP, UK; \\ and ${ }^{3}$ Unité de Recherches de Physiologie Animale, INRA, 78352 Jouy-en-Josas cedex, France
}

\begin{abstract}
The decline in pulsatile LH secretion and pituitary responsiveness to $\mathrm{GnRH}$ as pregnancy advances may be due to non-steroidal factors secreted by the ovine corpus luteum of pregnancy. Corpora lutea from ten ewes on days 7080 of gestation were homogenized, charcoal-treated and, together with charcoal-treated follicular fluid from superovulated women, were subjected to inhibin immunoaffinity chromatography, reducing dimeric inhibin $A$ and $B$ by $>90 \%$ and abolishing inhibin bioactivity. These preparations were investigated using cultures of rat pituitary cells. GnRH-induced LH and FSH secretion in vitro was reduced by ovine corpus luteum extract and human follicular fluid by $47 \pm 5 \%$ and $42 \pm 5 \%$ of control LH and by $37 \pm 5 \%$ and $50 \pm 10 \%$ of control FSH, respectively $(P<0.001)$. Extracts prepared from corpora lutea and placentae that were
\end{abstract}

collected on days 50, 90 and 120 of pregnancy (five ewes per stage of pregnancy) showed increased GnRH-induced LH-suppressing bioactivity, particularly in the case of the placental extracts, with a threefold increase in activity. When partially purified by pseudochromatofocusing, GnRH-induced LH-suppressing bioactivity in extracts of ovine corpora lutea was identified at pH 5.40 and 5.77. Although these values are similar to published gonadotrophin surge-attenuating factor (GnSAF) bioactivity pl values, a GnSAF-blocking antiserum had no consistent effect on ovine corpus luteum extract GnRH-induced LHsuppressing bioactivity. It was concluded that the ovine corpus luteum of pregnancy contains a non-steroidal, noninhibin factor, probably not GnSAF, that has the ability to reduce pituitary responsiveness to $\mathrm{GnRH}$ in vitro.

\section{Introduction}

Reduced pituitary responsiveness to $\mathrm{GnRH}$ (Chamley et al., 1974; Jenkin et al., 1977) coincides with a reduction in the content of pituitary LH (Chamley et al., 1976; Jenkin et al., 1977) and LH-secreting gonadotroph hypoplasia (Wise et al., 1986) in pregnant sheep. After parturition, GnRH pulse frequency and amplitude increase to cyclic values in ewes (Wise, 1990) and the decreased pituitary LH and mRNA content observed during gestation (Wise et al., 1985) is reversed. Because of the close relationship between $\mathrm{GnRH}$ and $\mathrm{LH}$ during the ovine oestrous cycle (Levine et al., 1982; Clarke et al., 1987), a reduction in GnRH signalling during gestation may be responsible for lowered LH synthesis. Evidence for this proposal is derived from hypothalamicpituitary gland disconnected ewes in which the absence of the GnRH signal leads to a reduction in synthesis and secretion of LH (Hamernik et al., 1986). Furthermore, in postpartum ewes, there is an increase in secretion of $\mathrm{LH}$ in response to exogenous GnRH (Wright et al., 1981)

Email: p.a.fowler@abdn.ac.uk and an increase in pituitary LH content (Jenkin et al., 1977), although the number of pituitary $\mathrm{GnRH}$ receptors remains similar (Crowder et al., 1982).

Increasing concentrations of steroid hormones during the third trimester of pregnancy in ewes (Thompson and Wagner, 1974; Challis and Patrick, 1981; Thomas et al., 1994) may be responsible for the long-term downregulation of $\mathrm{GnRH}$ secretion and the synthesis and release of gonadotrophin. This finding is supported by evidence that progesterone has oestradiol-dependent inhibitory effects on $\mathrm{LH}$ secretion and the ability to suppress the ovine oestradiol-induced LH surge (KasaVubu et al., 1992). However, evidence that non-steroidal factors from the ovary may play a role in the inhibition of $\mathrm{LH}$ secretion emerged from several investigations in pregnant and postpartum ewes. In a study to elucidate the role of the ovary in the control of $\mathrm{LH}$ secretion in the early puerperium in ewes, it was observed that pituitary and serum $\mathrm{LH}$ concentrations remain low during the last third of pregnancy. Subsequently, the rate of increase of $\mathrm{LH}$ after parturition was lower in intact ewes than in ewes from which the ovaries were removed at day 28 and pregnancy was maintained with progesterone implants 
(O'Reilly and Dziuk, 1973). The concept that nonsteroidal factors from the corpus luteum of pregnancy may play a role in the inhibition of pulsatile LH release during pregnancy was proposed by Al-Gubory (1989a). This proposal was based on the observation that the surgical removal of the corpus luteum at mid-pregnancy had no subsequent effects on plasma concentrations of progesterone and $\mathrm{FSH}$, although the frequency of $\mathrm{LH}$ pulses increased. Similarly, the frequency of $\mathrm{LH}$ pulses increased more rapidly in the puerperium in ewes from which the corpus luteum was removed at mid-pregnancy than in intact ewes (Al-Gubory et al., 1989b). These data were confirmed by a subsequent study demonstrating that charcoal-treated extracts of the corpus luteum of pregnancy, but not the corpus luteum of the oestrous cycle, muscle or fetal cotyledons, inhibited pulsatile LH secretion in ewes (Al-Gubory et al., 1992). In addition, the preliminary observation that serum from women in the third trimester of gestation contains marked gonadotrophin surge-attenuating factor (GnSAF) bioactivity (Fowler et al., 1995; Fowler and Templeton, 1996) introduces the possibility that the corpus luteum of pregnancy or the placenta may be a source of this non-steroidal hormone. Al-Gubory et al. (2003) reported that the pulsatile $\mathrm{LH}$ release and pituitary responsiveness to $\mathrm{GnRH}$ decreases progressively as pregnancy advances, but this study failed to support the hypothesis that ovarian and placental steroids are solely responsible for the inhibition of $\mathrm{LH}$ secretion and $\mathrm{GnRH}$-induced $\mathrm{LH}$ release during pregnancy in sheep.

The aim of the present study was to determine whether the corpus luteum of pregnancy and placental extracts contain specific bioactivity, distinct from ovarian steroids and inhibin, which could reduce pituitary responsiveness to $\mathrm{GnRH}$ in vitro.

\section{Materials and Methods}

\section{Preparations of ovine corpora lutea and placentae}

All procedures relating to the care and use of animals were approved by the French Ministry of Agriculture according to French regulations for animal experimentation. All corpora lutea were collected from ten Prealpes-du-Sud ewes (maintained at INRA, Jouyen-Josas) on days 70-80 of pregnancy. The corpora lutea were surgically removed as described by Al-Gubory et al. (1989a), snap-frozen in liquid nitrogen and then stored at $-20^{\circ} \mathrm{C}$ until use. The corpora lutea were thawed and the ovine luteal extracts at days 70-80 of gestation (oLE7080) were obtained as follows. Corpora lutea were minced and homogenized in $0.9 \%(\mathrm{w} / \mathrm{v})$ ice-cold saline. The homogenates were stirred for $1 \mathrm{~h}$ and centrifuged at $3000 \mathrm{~g}$ for $30 \mathrm{~min}$. The oLE70-80 preparation was subjected to twofold charcoal treatment (each for $24 \mathrm{~h}$ at $4{ }^{\circ} \mathrm{C}$ with $10 \mathrm{mg}$ charcoal $+1 \mathrm{mg}$ dextran per $\mathrm{ml}$ of extract) as described by Fowler et al. (1990). Subsequently, ovine luteal extracts (OLE) and ovine placental extracts (OPE) were prepared from corpora lutea of pregnancy and placental samples collected at days 50,90 and 120 of gestation (five ewes per stage of pregnancy). The samples were extracted in the same way and protein content determined in $\mathrm{ng} \mathrm{ml}^{-1}$ (oLE50, $23.3 \mathrm{ng} \mathrm{ml}^{-1}$; oLE90, $26.4 \mathrm{ng} \mathrm{ml}^{-1}$; oLE120 $19.2 \mathrm{ng} \mathrm{ml}^{-1}$ and OPE50, $12.7 \mathrm{ng}$ $\mathrm{ml}^{-1}$; oPE90, $8.0 \mathrm{ng} \mathrm{ml}^{-1}$; oPE120, $18.3 \mathrm{ng} \mathrm{ml}^{-1}$ ). After charcoal treatment, all extracts were centrifuged for $1 \mathrm{~h}$ at $105000 \mathrm{~g}$ at $4{ }^{\circ} \mathrm{C}$ before passage through $0.45 \mu \mathrm{m}$ filters. The resulting extracts were transported to Oxford Brookes University (half the oLE70-80) or the University of Aberdeen (half the oLE70-80 and oLE50, 90, 120 and oPE50, 90, 120) on dry ice.

\section{Human follicular fluid}

All protocols using human subjects were given Joint Ethical Committee Approval at Aberdeen and all patients gave informed consent. Over $500 \mathrm{ml}$ human follicular fluid (hFF) was aspirated from follicles of $18 \mathrm{~mm}$ in diameter from 40 women undergoing IVF in Aberdeen. The follicles were pooled, treated with charcoal (Fowler et al., 1990) to reduce concentrations of oestradiol and progesterone to $<0.07 \mathrm{nmol} \mathrm{I}^{-1}$ and $<1.3 \mathrm{nmol} \mathrm{I}^{-1}$, respectively, and desalted as described by Fowler et al. (2002). An aliquot of $100 \mathrm{ml}$ of this hFF was transported to Oxford Brookes University on dry ice. The hFF was used as a control in this study because it is known to contain a non-inhibin, non-steroidal factor, GnSAF, that reduces $\mathrm{GnRH}$-induced $\mathrm{LH}$ secretion (Fowler and Templeton, 1996).

\section{Inhibin depletion of oLE and hFF}

Aliquots of $100 \mathrm{ml}$ oLE70-80 and hFF were subjected to inhibin depletion using immobilized R1 monoclonal antibody which recognizes an epitope in the $\alpha$ inhibin subunit (Groome et al., 1995). Each $100 \mathrm{ml}$ aliquot of hFF and oLE was incubated overnight with $2 \mathrm{ml} \mathrm{HiTrap}^{\mathrm{TM}}$ (Pharmacia, Milton Keynes) NHS-activated gel carrying $20 \mathrm{mg}$ of the R1 antibody, which was then removed by centrifugation $(3000 \mathbf{g}, 30 \mathrm{mins})$. The process was repeated with fresh regenerated gel and the aliquots of OLE and hFF were then transported to the University of Aberdeen on dry ice. After inhibin depletion, protein concentrations of hFF and oLE were 53 and $12 \mathrm{mg} \mathrm{ml}^{-1}$, respectively. The content of inhibin $A$ and $B$ of the hFF had been reduced by $>90 \%$, whereas the inhibin content of the oLE was undetectable after depletion using the assays described by Knight et al. (1998).

\section{Rat pituitary cell culture bioassay}

Adult female Sprague-Dawley rats were maintained under a constant $12 \mathrm{~h}$ light: $12 \mathrm{~h}$ dark photoperiod at $22^{\circ} \mathrm{C}$ with access to food and water ad libitum. For each 
cell culture, 15 rats selected at random during the oestrous cycle were killed by stunning and cervical dislocation. Dispersion and culture of the pituitary cells was carried out as described in Fowler et al. (1994) and only preparations with $>75 \%$ viability of dispersed cells were used for bioassay. Primary pituitary cell cultures were at 100000 viable cells per $500 \mu \mathrm{l}$ culture medium per well in 48-well tissue culture plates. The cells were cultured under sterile conditions for $24 \mathrm{~h}$ at $37^{\circ} \mathrm{C}$ in a water-saturated atmosphere of $5 \%$ $\mathrm{CO}_{2}$ and $95 \%$ air mixture with serum-free defined culture medium (SFDM) as defined in Fowler et al. (1994). Media and non-attached cells were removed by aspiration and the wells washed with $500 \mu$ l SFDM. All experiments were then carried out on quadruplicate wells as follows: $450 \mu \mathrm{l}$ fresh SFDM was added, together with the treatments made up to $50 \mu$ l with SFDM. All the culture plates contained at least four control wells receiving SFDM only. After $24 \mathrm{~h}$ of incubation with the test substances, the media were collected and stored at $-20^{\circ} \mathrm{C}$ for determination of basal $\mathrm{LH}$ and $\mathrm{FSH}$ secretion. The wells were washed with fresh medium and then treated with $0.1 \mu \mathrm{mol}$ GnRH I ${ }^{-1}$ (Fertagyl: Intervet UK Ltd, Cambridge). Cultures were terminated after $4 \mathrm{~h}$ of incubation by collecting the media which was stored at $-20^{\circ} \mathrm{C}$ for determination of $\mathrm{GnRH}$-induced $\mathrm{LH}$ and $\mathrm{FSH}$ secretion.

\section{Dose-responses for assessment of bioactivities}

Doses of $0,0.4,2.0,10.0$ and $50.0 \mu \mathrm{l}$ per well of steroid-free oLE70-80 and hFF, with or without inhibin depletion, and oLE50, 90, 120 and OPE50, 90, 120, were added randomly to nine independent cultures of rat pituitary cells in quadruplicate wells. Each culture dish contained four control wells that received SFDM only and four wells received $50 \mu \mathrm{l}$ SFDM rather than $50 \mu \mathrm{l}$ $\mathrm{GnRH}$. This procedure enabled the calculation of $\mathrm{LH}$ release in the absence of $\mathrm{GnRH}$ stimulation to ensure comparable $\mathrm{GnRH}$ responses from one culture to another.

\section{Effect of anti-GnSAF polyclonal antibody}

Anti-GnSAF antiserum and a control rat polyclonal antiserum (antiserum raised against serum from three postmenopausal women: anti-PMWS) were mixed gently $1: 1$ in $100 \mu \mathrm{l}$ aliquots with oLE70-80 and hFF for $1 \mathrm{~h}$ at $37^{\circ} \mathrm{C}$ in 24-well dishes on an orbital shaker to determine whether the antiserum previously demonstrated to block GnSAF bioactivity in vitro in a range of human, bovine and rat preparations had the same effect (Fowler et al., 2002; P. A. Fowler, C. Price and N. Spears, unpublished). The incubation experiment was repeated three times. The samples were then applied to five separate bioassays at $0.5,5.0$ and $50.0 \mu \mathrm{l}$ per well. The use of the antiPMWS controlled for the effects of increasing serum concentration in the culture dish wells and the addition of rat IgG to rat pituitary cell monolayers.

\section{Pseudochromatofocusing of inhibin-depleted oLE and $h F F$}

Preliminary purification of oLE70-80 was performed by pseudochromatofocusing using $3.3 \mathrm{~g}$ Bakerbond CBX ${ }^{\mathrm{TM}}$ media (JT Baker Inc., Phillipsburg, NJ) packed into a $\mathrm{HR}^{\mathrm{TM}}$ 10/10 column (Amersham Pharmacia Biotech Little Chalfont) as described by Fowler and Price (1997). Volumes of $1.5 \mathrm{ml}$ oLE were equilibrated by desalting $0.75 \mathrm{ml}$ aliquots into $2 \mathrm{ml} \mathrm{2,} \mathrm{N-morpholino,}$ ethanesulfonic acid buffer (MES; Sigma-Aldrich Co. Ltd, Poole), pH 5.0, mixed 1:1 with MES buffer, adjusted to $\mathrm{pH} 5.0$, centrifuged at $2000 \mathrm{~g}$ for $15 \mathrm{~min}$, and passed through a $0.2 \mu \mathrm{m}$ filter before chromatography. The samples were pseudo-chromatofocused at $200 \mathrm{ml} \mathrm{h}^{-1}$. A pH gradient of 5-8.0 was generated by sequentially passing $30 \mathrm{ml}$ of $75 \%$ MES $+25 \%$ sodium acetate (500 mmol sodium acetate (NaAc) $\left.\mathrm{I}^{-1}, \mathrm{pH} 8.00\right)$, 50\% MES + 50\% NaAc and 25\% MES + 75\% NaAc through the column. Each run was terminated with $140 \mathrm{ml}$ of $100 \% \mathrm{NaAc}$ buffer. The $\mathrm{pH}$ of each of the fractions was determined before being concentrated to $1 \mathrm{ml}$ through Macrosep $^{\mathrm{TM}} 10 \mathrm{kDa}$ MWCO filters at $5000 \mathrm{~g}$ (Flowgen Instruments Ltd, Sittingbourne). Before the bioassay, each concentrated fraction was passed through a $0.2 \mu \mathrm{m}$ filter and double-desalted. The chromatography fractions were bioassayed at $5 \mu \mathrm{l}$ per well in two separate rat pituitary cell cultures.

\section{Hormone assays}

Concentrations of $\mathrm{LH}$ and $\mathrm{FSH}$ in cell-conditioned media from rat cultures were determined using homologous rat radioimmunoassays. Sensitivities and intraand interassay coefficients of variation values of these radioimmunoassays were: $0.6 \mathrm{ng} \mathrm{FSH} \mathrm{ml}^{-1}$ (NIDDKrFSH-RP-2) using NIDDK-anti-rFSH-S11 and 7.1 and $11.2 \%$, respectively, and $0.3 \mathrm{ng} \mathrm{LH} \mathrm{ml}{ }^{-1}$ (NIDDK-rLHRP3) using NIDDK-anti-rLH-S1 1 and 8.5 and $13.3 \%$, respectively. Commercial kits were used to determine oestradiol and progesterone concentrations in hFF and oLE as described in Fowler et al. (1990).

\section{Statistical analysis}

The in vitro pituitary responses are expressed as percentages of the relevant control gonadotrophin concentrations secreted from blank control wells on the same culture dishes, allowing data from different rat pituitary monolayer cultures to be pooled. The controls were wells exposed to SFDM alone (basal secretion), both overnight and during the $4 \mathrm{~h}$ exposure to $\mathrm{GnRH}$, and wells exposed to SFDM + $0.1 \mu \mathrm{mol}$ GnRH I-1 $(\mathrm{GnRH}-$ induced secretion) during the $4 \mathrm{~h}$ GnRH challenge. The differences between treatments and dose-responses 

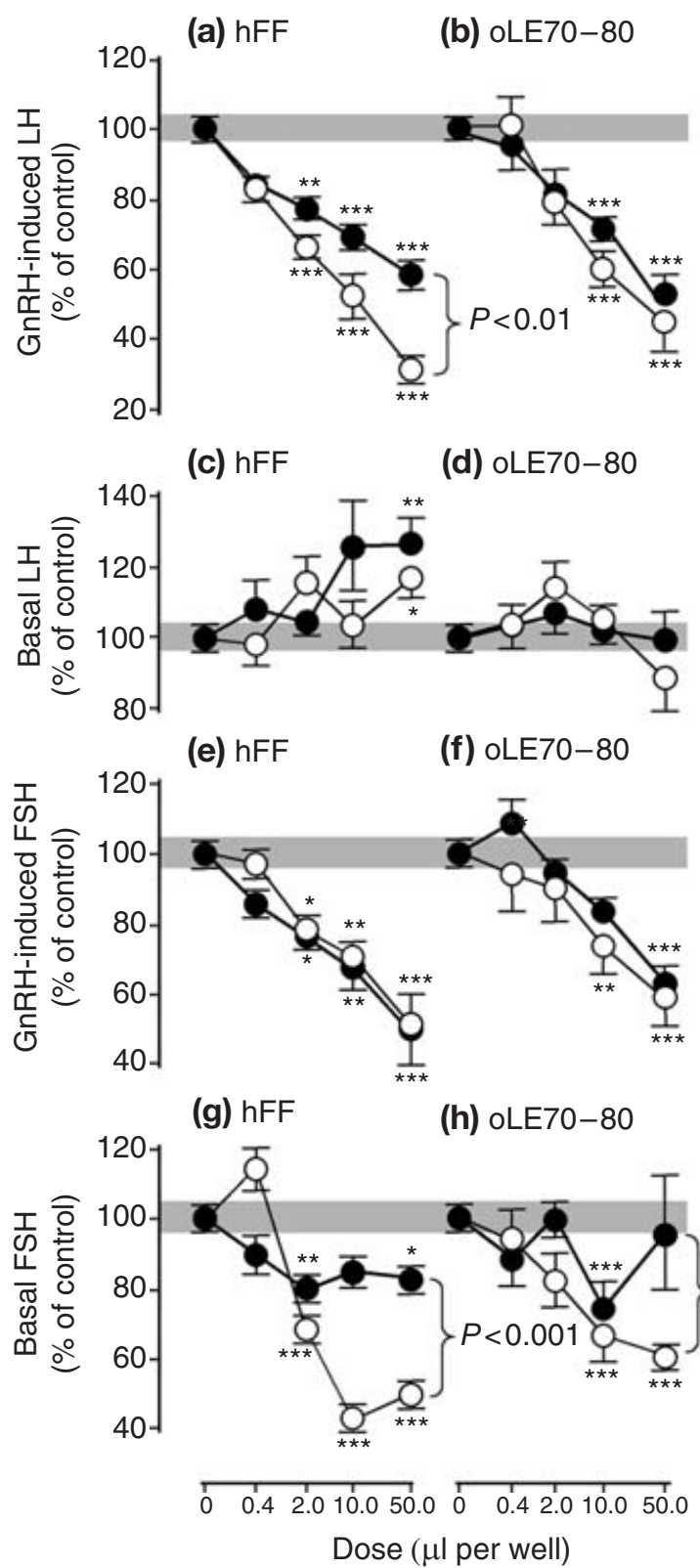

Fig. 1. Dose-dependent effects of steroid-free $(a, c, e, g)$ human follicular fluid (hFF) and (b, d,f,h) ovine luteal extracts at days 70-80 of pregnancy (oLE70-80), both with $(\bullet)$ and without $(\bigcirc)$ inhibin depletion, on $(\mathrm{a}, \mathrm{b}) \mathrm{GnRH}$-induced and (c,d) basal $\mathrm{LH}$ secretion and on $(\mathrm{e}, \mathrm{f}) \mathrm{GnRH}$-induced and $(\mathrm{g}, \mathrm{h})$ basal $\mathrm{FSH}$ secretion from two different rat pituitary gland monolayers. The horizontal shaded bar represents the SEM range for control secretion. Significance values are by ANOVA relative to controls (culture medium only), ${ }^{*} P<0.05,{ }^{* *} P<0.01,{ }^{* * *} P<0.001$, with the significance of effects of inhibin depletion shown by brackets and $P$ values, $n=2 \times 4$; plotted values are means \pm SEM.

were assessed by two-way ANOVA. Differences between specific categories were tested by Dennett's post hoc test (comparison of tests with control). Median effective doses ( $\mathrm{ED}_{50}$ value) for GnSAF bioactivity (defined as the $\mu \mathrm{l}$ of hFF or extract per well dose required to produce $50 \%$ of the greatest suppression of secretion observed, converted to $\mathrm{mg}$ of protein) were calculated from the dose-response curves using log-linear regression equations fitted separately for each dose-response curve. The analyses were performed using the Statview 4.02 programme (Abacus Concepts Inc., Berkley, CA). All results are presented as means \pm SEM.

\section{Results}

Effects of oLE70-80 hFF on gonadotrophin secretion

All four preparations (steroid-free oLE70-80 and hFF with or without inhibin depletion) significantly suppressed $\mathrm{GnRH}$-induced LH secretion (ANOVA, $P<0.001$; Fig. $1 \mathrm{a}, \mathrm{b})$ by up to $47 \pm 5 \%$ and $68 \pm 4 \%$ (hFF) and $42 \pm 5 \%$ and $49 \pm 11 \%$ (oLE70-80), respectively, but had no dose-response effect on basal LH (Fig. 1c,d). Both hFF preparations, but not the oLE70-80 preparations, caused some stimulation of basal $\mathrm{LH}$ at the highest dose (by $28 \pm 8 \%$ and $18 \pm 6 \%$, ANOVA, $P<0.05 ; P<0.01)$. Inhibin-depleted hFF and oLE70-80 significantly suppressed GnRH-induced FSH secretion (Fig. $1 \mathrm{e}, \mathrm{f}$ ) by up to $50 \pm 10 \%$ and $37 \pm 5 \%$ (ANOVA, $P<0.001)$. In contrast, only the non-depleted hFF and oLE70-80 suppressed basal FSH in a significant dosedependent manner, with a maximal suppression of $51 \pm$ $4 \%$ and $36 \pm 5 \%$ (ANOVA, $P<0.001$ ), respectively. However, inhibin-depleted hFF and oLE70-80 did cause some suppression of basal FSH secretion (by $20 \pm 4 \%$ and $25 \pm 8 \%$, ANOVA, $P<0.05 P<0.001)$, although this was not in a dose-dependent manner (Fig. 1g,h).

The $\mathrm{ED}_{50}$ values for these effects on gonadotrophin secretion (Table 1) showed that inhibin-depleted hFF had less effect on $\mathrm{GnRH}$-induced $\mathrm{LH}$ secretion than did steroid-free oLE70-80 or hFF. Inhibin-depleted hFF had the greatest effect on GnRH-induced FSH, whereas only non-depleted hFF and oLE70-80 contained marked inhibin bioactivity in terms of reducing basal FSH secretion.

\section{Effect of rat anti-GnSAF polyclonal on antiserum inhibin-depleted oLE70-80 bioactivity}

Incubation of oLE70-80 with either the rat GnSAFblocking polyclonal antiserum or antiserum raised against serum proteins from post-menopausal women had no effect on the suppression of GnRH-induced $\mathrm{LH}$ secretion in vitro (Fig. $2 \mathrm{~b}$ ), with $\mathrm{GnRH}$-induced $\mathrm{LH}$ secretion $58 \pm 7 \%$ and $56 \pm 4 \%$ of control, respectively (ANOVA, this result was not significant). However the blocking antiserum clearly blocked GnSAF bioactivityin hFF (Fig. 2a), with GnRH-induced LH secretion at $96 \pm 6 \%$ of control in the presence of the blocking antiserum compared with $64 \pm 9 \%$ of control in the presence of the non-specific antiserum (ANOVA, $P<0.001$ ). 
Table 1. Median effective doses ( $\mathrm{ED}_{50}$ values) for $\mathrm{GnRH}$-induced $\mathrm{LH}$-suppressing bioactivity and inhibin bioactivity in steroid-free non-depleted and in steroid-free inhibin-depleted hFF and oLE70-80

\begin{tabular}{|c|c|c|c|c|}
\hline & \multicolumn{2}{|c|}{$\begin{array}{l}\text { Inhibin-depleted, steroid-free } \\
\text { preparations }\end{array}$} & \multicolumn{2}{|c|}{$\begin{array}{l}\text { Steroid-free, non-depleted } \\
\text { preparations }\end{array}$} \\
\hline & hFF & oLE70-80 & hFF & oLE70-80 \\
\hline & \multicolumn{4}{|c|}{$\mathrm{ED}_{50}(\mathrm{mg}$ protein per well) } \\
\hline GnRH-LH & 1.44 & 0.18 & 0.11 & 0.15 \\
\hline GnRH-FSH & 0.09 & 0.24 & 0.20 & 0.20 \\
\hline Basal FSH & $*$ & $*$ & 0.14 & 0.26 \\
\hline Basal LH & $*$ & $*$ & $*$ & $*$ \\
\hline
\end{tabular}

*No significant dose-response effect: $\mathrm{ED}_{50}$ value not calculated.

hFF: human follicular fluid; oLE70-80: ovine luteal extracts at days 70-80 of gestation.

(a) hFF

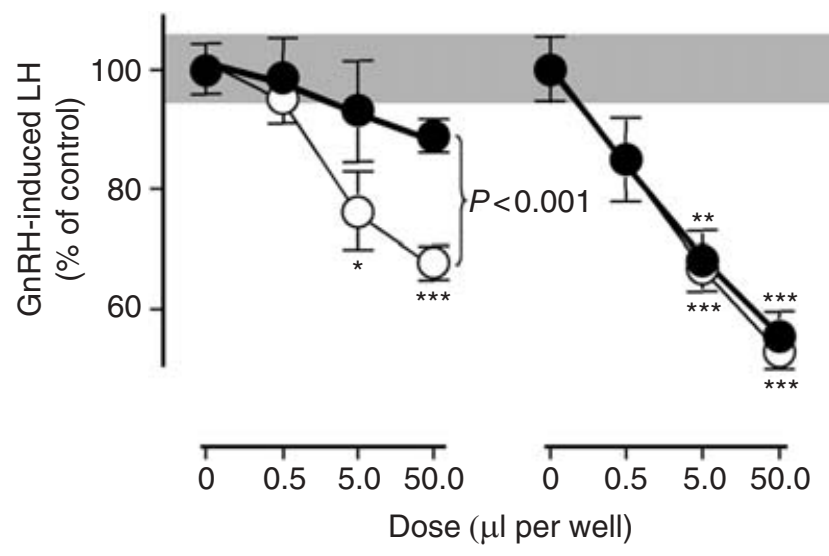

Fig. 2. Dose-dependent effects of steroid-free, inhibin-depleted, human follicular fluid (hFF) and ovine luteal extracts at days 70-80 of pregnancy (oLE70-80) after incubation with antigonadotrophin surge-attenuating factor (GnSAF) antiserum $(\bullet)$ or anti-post-menopausal woman serum antiserum $(O)$ on $\mathrm{GnRH}$ induced $\mathrm{LH}$ secretion from five different rat pituitary monolayers. The horizontal shaded bar represents the SEM range for control secretion. Significance values are by ANOVA relative to controls (culture medium only), ${ }^{*} P<0.05,{ }^{* *} P<0.01,{ }^{* * *} P<0.001$, with the significance of effects of antibody treatment shown by brackets and $P$ values, $n=5 \times 4$; plotted values are means \pm SEM.

\section{Effect of $O L E$ and $O P E$ on GnRH-induced LH secretion}

All six preparations (OLE50, 90, 120 and oPE50, 90, 120) significantly reduced $\mathrm{GnRH}$-induced $\mathrm{LH}$ secretion to below $60 \%$ of control (Fig. 3). However, although the oLE preparations showed only a moderate increase in GnRH-induced LH-suppressing bioactivity as pregnancy continued $\left(\mathrm{ED}_{50}\right.$ value decreasing from $0.15 \mathrm{mg}$ to $0.10 \mathrm{mg}$ from day 50 to day 120 of gestation, ANOVA, not significant), there was a threefold increase in $\mathrm{GnRH}$-induced LH-suppressing bioactivity in the oPE preparations $\left(\mathrm{ED}_{50}\right.$ value decreasing from $0.27 \mathrm{mg}$ to

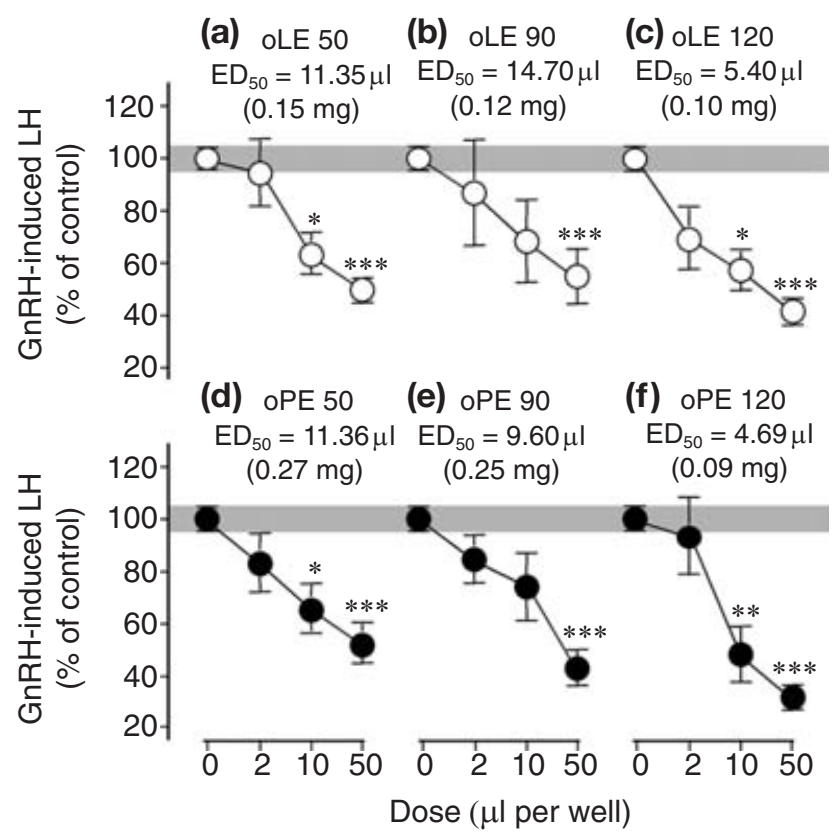

Fig. 3. Dose-dependent effects of steroid-free extracts of ovine corpora lutea of pregnancy (ovine luteal extracts (oLE; $a, b, c)$ ) and ovine placenta (ovine pituitary extracts (oPE; d,e,f)) collected on $(a, d)$ day 50, (b,e) day 90 and $(c, f)$ day 120 of gestation on $\mathrm{GnRH}$-induced LH secretion from two different rat pituitary monolayers. The horizontal shaded bar represents the SEM range for control secretion. Significance values are by ANOVA relative to controls (culture medium only), ${ }^{*} P<0.05,{ }^{* *} P<0.01,{ }^{* * *} P<0.001, n=3 \times 4$; plotted values are means \pm SEM.

$0.09 \mathrm{mg}$ from day 50 to day 120 of gestation, ANOVA, $P<0.01)$.

\section{Partial purification of inhibin-depleted oLE70-80 GnRH-induced LH-suppressing bioactivity}

The $\mathrm{pH}$ gradient-driven protein elution profiles for steroid-free, inhibin-depleted oLE (Fig. 4) were similar 


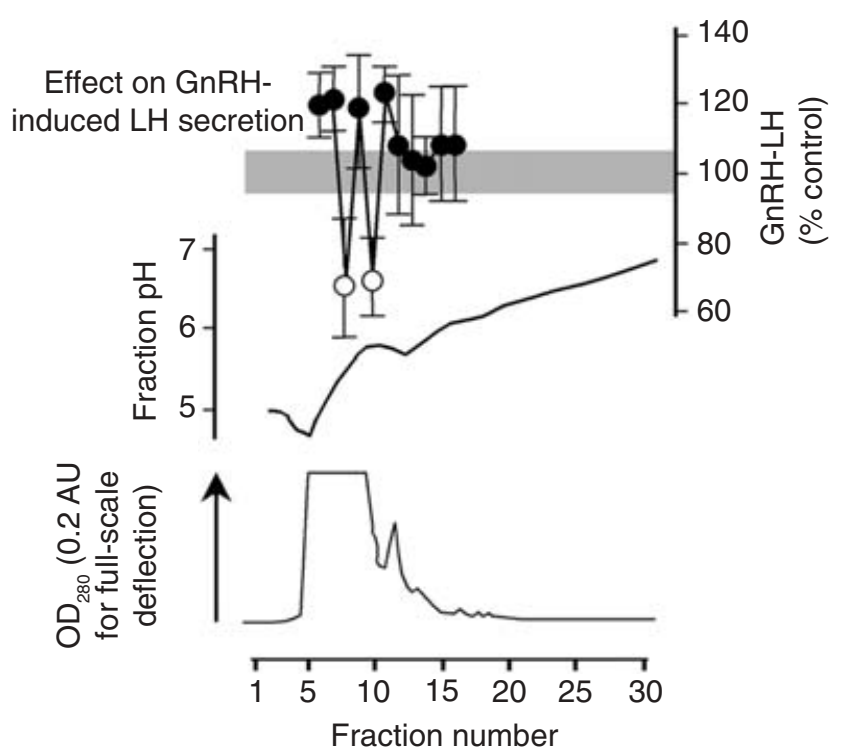

Fig. 4. Pseudochromatofocusing resolution of $\mathrm{GnRH}$-induced LH suppressing bioactivity in inhibin-depleted, steroid-free, ovine luteal extracts at days $70-80$ of pregnancy. The thin line shows the protein elution profile at $280 \mathrm{~nm}$ and the thick line shows the $\mathrm{pH}$ of the fractions eluted from the column. GnRH-induced $\mathrm{LH}$ secretion $(-)$ and the elution of suppressive bioactivity $(\mathrm{O})$ at $\mathrm{pH} 5.40+5.77$. The horizontal shaded bar represents the SEM range for control secretion. $n=2 \times 4$; plotted values are means \pm SEM.

to those observed for hFF and bovine serum (Fowler and Price, 1997) and for granulosa-luteal cell-conditioned medium (Fowler et al., 2002). The oLE70-80 contained clear bioactivity that suppressed $\mathrm{GnRH}$-induced $\mathrm{LH}$ secretion $(\mathrm{GnRH}$-induced $\mathrm{LH}$ secretion reduced by $30 \pm 17 \%$ and $29 \pm 12 \%$, respectively, ANOVA, $P<0.01)$ and eluted at $\mathrm{pH} 5.40$ and $\mathrm{pH} 5.77$ by pseudochromatofocusing.

\section{Discussion}

The present study demonstrates conclusively that the ovine corpus luteum of pregnancy contains nonsteroidal, non-inhibin bioactivity that reduces pituitary gland responsiveness to $\mathrm{GnRH}$ in vitro. Extracts of the ovine corpus luteum significantly reduced the release of both $\mathrm{LH}$ and FSH from cultured rat gonadotrophs by $\mathrm{GnRH}$. However, this bioactivity did not have dosedependent effects on basal gonadotrophin secretion. The behaviour of the steroid-free, inhibin-depleted oLE70-80 extract in our established rat pituitary cell culture bioassay, with pl values of 5.40 and 5.77, was markedly similar to that of steroid-free, inhibin-depleted human ovarian GnSAF (pH 5.25 and $\mathrm{pH}$ 5.75, Mroueh et al., 1996; pH 5.74 and pH 5.77, Fowler et al., 2002).
Furthermore, preliminary data indicate that serum from women in the third trimester of gestation contains GnSAF bioactivity (Fowler et al., 1995). However, the observation in the present study that a GnSAF antiserum which blocks human GnSAF (Fowler et al., 2002) and bovine and rat GnSAF (P. A. Fowler, C. Price and N. Spears, unpublished), but not oLE70-80 bioactivity, does not support the conclusion that the ovine corpus luteum $\mathrm{GnRH}$-induced $\mathrm{LH}$-suppressing bioactivity is the same as GnSAF.

The removal of almost all of the oestradiol and progesterone from the ovine corpus luteum extracts before bioassay indicates that the bioactivity in ovine corpus luteum extract that suppresses pituitary gland responsiveness to $\mathrm{GnRH}$ is distinct from ovarian steroids. In addition, long-term ( $24 \mathrm{~h})$ exposure of rat gonadotrophs to oestradiol in vitro had little effect on $\mathrm{GnRH}$ induced LH secretion (Speight and Fink, 1981; Byrne et al., 1995). Continued exposure to oestradiol during a GnRH challenge augments GnRH-induced LH release and synthesis (Ramey et al., 1987), whereas the coadministration of progesterone with $\mathrm{GnRH}$ augments $\mathrm{LH}$ release from rat pituitary gland monolayers (Geiger et al., 1980; Leigh et al., 1994). It is reasonable to conclude that the effects of ovine corpus luteum extracts in the present study were not due to the trace quantities of steroid hormones remaining after charcoal treatment.

Although inhibin has marked suppressive effects on FSH secretion, its suppressive effects on $\mathrm{LH}$ release from cultured rat gonadotrophs are seen only at higher doses: reducing $\mathrm{GnRH}$-induced $\mathrm{LH}$ secretion (Campen and Vale, 1988), gonadotrophin subunit mRNA expression (Attardi et al., 1989, 1991) and GnRH receptor expression (Wang et al., 1989; Braden et al., 1990) or binding (Wang et al., 1988). The present study compared inhibin containing hFF with inhibin depleted of hFF. Inhibin without hFF, unlike inhibin containing hFF, did not suppress basal FSH secretion below $80 \%$ of the control value, demonstrating that very little inhibin bioactivity remained. Despite this finding, both preparations reduced GnRH-induced $\mathrm{LH}$ secretion to $<60 \%$ of the control value. This finding supports the conclusion that the ovine corpus luteum extract treated in the same way reduced GnRH-induced $\mathrm{LH}$ secretion because of some bioactive component other than inhibin. This contention is reinforced by findings that inhibin is reduced by day 90 of gestation in the ewe (Knight et al., 1998), the opposite of the increasing $\mathrm{GnRH}$-induced $\mathrm{LH}$-suppressing effects observed in the present study.

The present study has demonstrated that the ovine corpus luteum of pregnancy produces a non-steroidal, non-inhibin bioactivity which would be able to damp pituitary responsiveness to $\mathrm{GnRH}$ during pregnancy. It has been suggested that high steroid hormone concentrations during late pregnancy in the ewe (Thompson and Wagner, 1974; Challis and Patrick, 1981; Thomas et al., 1994) may be responsible for long-term downregulation 
of GnRH secretion. Interestingly, administration of oestradiol significantly reverses the long-term downregulation of $\mathrm{GnRH}$ receptor expression and binding, but not LH expression, in GnRH agonist-treated ewes (Brooks and McNeilly, 1994). Although there is no data on $\mathrm{GnRH}$ pulsatility during gestation in the ewe, regular LH pulsatility is absent in the peri-implantation period (Al-Gubory, 1999) and throughout pregnancy (Al-Gubory et al., 2003). It is also known that in pregnant women circulating $\mathrm{GnRH}$ titres decrease during gestation (Siler-Khodr et al., 1984). In addition, although $\mathrm{GnRH}$ pulse frequency remains unchanged in pregnant women, GnRH pulse amplitude during late gestation is half that seen in early gestation (Petraglia et al., 1994). Furthermore, ovine pituitary responsiveness to GnRH in the short-term in vitro is not a result of decreased GnRH receptor expression after day 45 of pregnancy (Fowler and McNeilly, 1997). By day 60 of pregnancy, at a time when circulating concentrations of progesterone are similar to those measured on day 10 of the oestrous cycle, a marked inhibition of pulsatile $\mathrm{LH}$ release and pituitary responsiveness to $\mathrm{GnRH}$ has been shown to occur as compared with those on day 10 of the oestrous cycle (Al-Gubory et al., 2003). This finding indicates that sustained high concentrations of progesterone cannot be the sole cause of the inhibition of pulsatile LH secretion. If oestradiol is an important inhibitor of LH pulse amplitude and frequency observed on day 60 and day 120 of pregnancy (Al-Gubory et al., 2003), then circulating concentrations of this steroid should be noticeably increased after mid-pregnancy. This is probably not the case as the concentrations of circulating oestradiol remained very low throughout pregnancy and increased only in the last few days of pregnancy (Tsang, 1978). Therefore, the ability of nonsteroidal factors from the ovine corpus luteum of pregnancy, and indeed the placenta, to suppress pituitary responsiveness to GnRH would be important in the prevention of an untimely increase in gonadotrophin secretion and subsequent follicular development.

It is concluded that the corpus luteum of pregnancy in sheep produces a non-steroidal, non-inhibin, bioactivity that suppresses pituitary gland responsiveness to $\mathrm{GnRH}$ in vitro. Although this bioactivity has some similarities to the putative ovarian hormone GnSAF, it is probably a distinct entity.

The authors are grateful to M. Fraser and P. Cunningham for their expert technical assistance. The authors also thank the staff at the Medical School Animal House (University of Aberdeen) for maintaining the rats used in this study and the animal care staff of Jouy-en-Josas (INRA, France) for the excellent service. The authors are grateful to A. F. Parlow at NIDDK's National Hormone and Pituitary Program (Torrance, California) and SAPU (Carluke Hospital, Scotland) for the radioimmunoassay materials. This work was supported by INRA and the chromatography developed as part of an MRC (UK) funded project.

\section{References}

Al-Gubory KH (1999) Absence of regular pulsatile LH secretion during pre- and post-implantation periods in sheep European Journal of Endocrinology 141 521-525

Al-Gubory KH, Blanc MR and Martinet J (1989a) Role of the corpus luteum of pregnancy in controlling pituitary gonadotrophin secretion during the early post-partum period in the ewe Journal of Reproduction and Fertility 86 697-703

Al-Gubory KH, Blanc MR, Poirier JC, Solari A and Martinet J (1989b) Evidence that the corpus luteum of pregnancy contributes to the control of tonic secretion of LH in the ewe Journal of Reproduction and Fertility 85 125-131

Al-Gubory KH, Martinet J, Blanc MR, Poirer JC and Solari A (1992) Evidence for a gonadal non-steroidal factor that specifically inhibits release of luteinizing hormone in ewes Journal of Reproduction and Fertility $\mathbf{9 6}$ 509-519

Al-Gubory KH, Hervieu J and Fowler PA (2003) Effects of pregnancy on pulsatile secretion of luteinizing hormone $(\mathrm{LH})$ and gonadotropinreleasing hormone-induced LH release in sheep: a longitudinal study Reproduction 125 347-355

Attardi B, Keeping HS, Winters SJ, Kotsuji F and Troen P (1989) Effect of inhibin from primate Sertoli cells and $\mathrm{GnRH}$ on gonadotrophin subunit mRNA in rat pituitary cell cultures Molecular Endocrinology 3 12361242

Attardi B, Keeping HS, Winters SJ, Kotsuji F and Troen P (1991) Comparison of the effects of cyclohexamide and inhibin on the gonadotropin subunit messenger ribonucleic acid Endocrinology 128 119-125

Braden TD, Farnworth PG, Burger HG and Conn PM (1990) Regulation of the synthetic rate of gonadotrophin-releasing hormone receptors in rat pituitary cell cultures by inhibin Endocrinology 127 2387-2392

Brooks J and McNeilly AS (1994) Regulation of gonadotrophin-releasing hormone receptor mRNA expression in the sheep Journal of Endocrino$\log y \mathbf{1 4 3} 175-182$

Byrne B, Fowler PA, Fraser M, Culler M and Templeton A (1995) GnSAF bioactivity in serum from superovulated women is not blocked by inhibin antibody Biology of Reproduction 52 88-95

Campen CA and Vale W (1988) Interaction between purified ovine inhibin and steroids on the release of gonadotropins from cultured rat pituitary cells Endocrinology 123 1320-1328

Challis JR and Patrick JE (1981) Fetal and maternal estrogen concentrations throughout pregnancy in the sheep Canadian Journal of Physiology and Pharmacology 59 970-978

Chamley WA, Findlay JK, Cumming IA, Buckmaster JM and Goding JR (1974) Effect of pregnancy on the LH response to synthetic gonadotropinreleasing hormone in the ewe Endocrinology 94 291-293

Chamley WA, Jonas HA and Parr RA (1976) Content of LH, FSH, and growth hormone in the pituitaries of pregnant and anestrous sheep Endocrinology 98 1535-1538

Clarke IJ, Thomas GB, Yao B and Cummings JT (1987) GnRH secretion throughout the ovine estrous cycle Neuroendocrinology 46 82-88

Crowder ME, Gilles PA, Moss GE and Nett TM (1982) Pituitary content of gonadotropins and $\mathrm{GnRH}$-receptors in pregnant, postpartum and steroid-treated OVX ewes Journal of Animal Science 54 1235-1242

Fowler PA and McNeilly AS (1997) Maternal pituitary gonadotroph function in relation to $\mathrm{GnRH}$ receptor and $\mathrm{LH} \beta$ mRNA content during pregnancy in ewes Journal of Reproduction and Fertility 110 267-278

Fowler PA and Price C (1997) Follicle-stimulating hormone stimulates circulating gonadotropin surge-attenuating/inhibiting factor bioactivity in cows Biology of Reproduction 57 278-285

Fowler PA and Templeton A (1996) The nature and function of putative gonadotropin surge-attenuating/inhibiting factor (GnSAF/IF) Endocrine Reviews 17 103-120

Fowler PA, Messinis IE and Templeton AA (1990) Inhibition of LHRHinduced $\mathrm{LH}$ and $\mathrm{FSH}$ release by gonadotrophin surge-attenuating factor (GnSAF) from human follicular fluid Journal of Reproduction and Fertility 90 587-594

Fowler PA, Fraser M, Cunningham P, Knight PG, Byrne B, McLaughlin E, Wardle PG, Hull MG and Templeton A (1994) Higher gonadotrophin 
surge-attenuating factor (GnSAF) bioactivity is found in small follicles from superovulated women Journal of Endocrinology 14 33-44

Fowler PA, Knight PG and Templeton A (1995) Evidence for gonadotropin surge-attenuating factor (GnSAF) in serum from pregnant women Biology of Reproduction $\mathbf{5 2}$ Supplement 187

Fowler PA, Mason HD, Melvin WT, Wilson Y, Cash P, Sorsa-Lesley T and Harris W (2002) A 60-66 kDa protein with gonadotrophin surgeattenuating factor (GnSAF) bioactivity is produced by human ovarian granulosa cells Molecular Human Reproduction 8 823-832

Geiger JM, Plas-Roser S and Aron C (1980) Mechanisms of ovulation in female rats treated with $\mathrm{FSH}$ at the beginning of the estrous cycle: changes in pituitary responsiveness to luteinizing hormone $(\mathrm{LHRH})$ Biology of Reproduction 22 837-845

Groome NP, Illingworth PJ, O'Brien M, Priddle J, Weaver K and McNeilly AS (1995) Quantification of inhibin pro-alpha c-containing forms in human serum by a new ultrasensitive two-site enzyme-linked immunosorbent assay Journal of Clinical Endocrinology and Metabolism 80 2926-2932

Hamernik DL, Crowder ME, Nilson JH and Nett TM (1986) Measurement of messenger ribonucleic acid for luteinizing hormone $\beta$-subunit, $\alpha$ subunit, growth hormone and prolactin after hypothalamic pituitary disconnection in ovariectomised ewes Endocrinology 119 2704-2710

Jenkin G, Heap RB and Symons DBA (1977) Pituitary responsiveness to synthetic LH-RH and pituitary LH content at various reproductive stages in the sheep Journal of Reproduction and Fertility 49 207-214

Kasa-Vubu JZ, Dahl GE, Evans NP, Thrun LA, Moenter SM, Padmanabhan V and Karsch FJ (1992) Progesterone blocks the estradiol-induced gonadotropin discharge in the ewe by inhibiting the surge of gonadotropin-releasing hormone Endocrinology 131 208-212

Knight PG, Feist SA, Tanetta DS, Bleach ECL, Fowler PA, O'Brien M and Groome NP (1998) Measurement of inhibin-A ( $\alpha \beta A$ dimmer) during the oestrous cycle, and manipulation of ovarian activity and during pregnancy in ewes Journal of Reproduction and Fertility 113 159-166

Leigh AJ, Chapman AJ, Shakil T and Wilson CA (1994) The physiochemical, immunological and biological properties of rat pituitary and plasma $\mathrm{LH}$ Journal of Reproduction and Fertility 101 489-499

Levine JE, Pau K-YF, Ramirez VD and Jackson GL (1982) Simultaneous measurement of luteinizing hormone-releasing hormone and luteinizing hormone release in unanesthetized, ovariectomized sheep Endocrinology 111 1449-1455

Mroueh JM, Arbogast LK, Fowler PA, Templeton A, Friedman CI and Danforth D (1996) Identification of gonadotropin surge-inhibiting factor (GnSIF)/attenuin in human follicular fluid Human Reproduction 11490 496

O'Reilly PJ and Dziuk PJ (1973) Change in the level of LH in the sera and pituitaries of ovaiectomized and intact ewes at parturition Endocrinology 92 1575-1578

Petraglia F, Genazzani AD, Aguzzoli L, Gallinelli A, de Vita D, Caruso A and Genazzani AR (1994) Pulsatile fluctuations of plasma gonadotropinreleasing hormone and corticotropin-releasing factor levels in healthy pregnant women Acta Obstetricia et Gynecologica Scandinavica 73 284-289

Ramey JW, Highsmith RF, Wilfinger WW and Baldwin DM (1987) The effects of gonadotropin-releasing hormone and estradiol on luteinizing hormone biosynthesis in cultured rat anterior pituitary cells Endocrinology 120 1503-1513

Siler-Khodr TM, Khodr GS and Valenzuela G (1984) Immunoreactive gonadotropin-releasing hormone level in maternal circulation throughout pregnancy American Journal of Obstetrics and Gynecology 150 376-379

Speight A and Fink G (1981) Comparison of steroid and LH-RH effects on the responsiveness of hemipituitary glands and dispersed pituitary cells Molecular and Cellular Endocrinology 24 267-281

Thomas GB, McNeilly AS, Gibson F and Brooks AN (1994) Effects of pituitary-gonadal suppression with a gonadotrophin-releasing hormone agonist on fetal gonadotrophin secretion, fetal gonadal development and maternal steroid secretion in the sheep Journal of Endocrinology $141317-324$

Thompson FN and Wagner WC (1974) Plasma progesterone and oestrogens in sheep during late pregnancy: contribution of the maternal adrenal and ovary Journal of Reproduction and Fertility 41 57-66

Tsang CPW (1978) Plasma level of estrone sulfate, free estrogens and progesterone in the pregnant ewe throughout gestation Theriogenology 10 97-110

Wang QF, Farnworth PG, Findlay JK and Burger HG (1988) Effects of purified $31 \mathrm{kDa}$ bovine inhibin on the specific binding of $\mathrm{GnRH}$ to rat anterior pituitary cells in culture Endocrinology 123 2161-2166

Wang QF, Farnworth PG, Findlay JK and Burger HG (1989) Inhibitory effects of pure 31-kilodalton bovine inhibin on gonadotrophin-releasing hormone $(\mathrm{GnRH})$-induced up-regulation of $\mathrm{GnRH}$ binding sites in cultured rat anterior pituitary cells Endocrinology 124 363-368

Wise ME (1990) Gonadotropin-releasing hormone secretion during the postpartum anestrous period of the ewe Biology of Reproduction 43 719-725

Wise ME, Nilson JH, Nejedlik MT and Nett TM (1985) Measurement of messenger RNA for luteinizing hormone -subunit and -subunit during gestation and the postpartum period in ewes Biology of Reproduction 33 1009-1015

Wise ME, Sawyer HR and Nett T (1986) Functional changes in luteinizing hormone-secreting cells from pre- and postpartum ewes American Journal of Physiology 250 E282-E287

Wright PJ, Jenkin G and Heap RB (1981) Prolactin and LH release in response to $\mathrm{LH}-\mathrm{RH}$ and $\mathrm{TRH}$ in ewes during dioestrus, pregnancy and post partum Journal of Reproduction and Fertility 62 447-453

Received 10 January 2003

First decision 24 February 2003.

Revised manuscript received 4 March 2003.

Accepted 11 March 2003. 